\title{
Analysis on Characteristics of Water Regime disaster in Floor Season of Western China in 2017
}

\author{
Xiaoting $\mathrm{Li}^{1, \mathrm{a}}$, Peinan Zheng ${ }^{2, \mathrm{~b}}$, Jian $\mathrm{Xu}^{1, \mathrm{c}}$ \\ ${ }^{1}$ No.69 north third ring road, haidian district, Beijing, China.100088 \\ ${ }^{2}$ Mailbox No.2433, Beijing, China. 100081

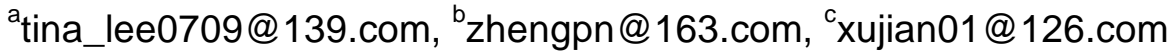

\begin{abstract}
Keywords: western region, 2017 flood season, water regime, disaster situation, characteristics analysis

Abstract. The western region of China is vast in territory and rich in water resources. It is the birthplace and upstream region of great rivers such as the Yangtze River, the Yellow River and Brahmaputra River. During the flood season, flood disasters and secondary disasters such as landslides, mudslides and dammed lake caused huge losses to the local residents. It need further attention and strengthen the analysis of flood season hydrological and disaster in the western region. This paper first introduces the basic situation of China's western area survey and flood season; secondly, to speak with the data, analysis of the 2017 flood season hydrological characteristics of the western region; thirdly, with the "Yangtze River 1 flood", "Jiuzhaigou earthquake" as examples, analyzes the characteristics of flood disaster in 2017 the western region; at the end of the paper, give out the summary and puts forward some opinions and suggestions to the Western sections hydrological disaster prevention and response, reduce the risk in flood season.
\end{abstract}

\section{Introduction}

China's western region of Xinjiang, Gansu, Ningxia, Qinghai, Shanxi, Sichuan, Chongqing, Tibet, Guizhou, Yunnan, Inner Mongolia, Guangxi and Hunan xiangxi, and two in hubei enshi tujia and miao autonomous prefecture of 12 provinces, municipalities and autonomous regions. The region is vast and sparsely populated. It is a region that is underdeveloped and needs to be developed. Most of the poverty-stricken people who have not yet had enough food in the country are distributed in this area, which is also an area where ethnic minorities gather in China. Its land area is 5.38 million square kilometers, accounting for $56 \%$ of the total land area. Currently, the population is about 287 million, accounting for 22.99 percent of the population. The western part of our country is contiguous with more than ten countries, and the land border is $12747 \mathrm{~km}$. The natural resources in the western region are particularly rich, and the total amount of water can be $82.5 \%$ of the whole country, and the development of hydropower resources is $77 \%$ of the whole country, but less than $1 \%$ of the development and utilization is still available[1].

The flood season refers to the period when the river water rises regularly during the year, and the water level rises in a certain period of the year due to the seasonal precipitation or melting of snow and ice in the river basin. "Flood" is the appearance of water, "flood season" is the period of the river water; under natural conditions, there may not be any flood in flood season, but floods usually occur in flood season [2]. Due to the difference of topography, topography and rainy season, the time of flood season does not coincide [3]. The river south of the Yangtze river can form floods in early summer, and in the vast areas of western China, the flood season usually refers to June to September.

\section{Water analysis of flood season in western China in 2017}

Since the beginning of June, the average rainfall in the western region has been $19.1 \%$ more than that of the same period of the year, and the south-eastern part of the southwest region is more obvious (see figure 1a). In July, the average rainfall in the western region was $14.3 \%$ less than that of the same period, and the eastern part of the southwest region was less obvious (see figure 1b). In August in the 
western region of average rainfall by more than $23.8 \%$ from the same period a year round, southeast of the northwest and more obvious in the west and Midwest of Inner Mongolia and other places less (see figure $1 \mathrm{c}$ ). In September, the average rainfall in the western region was slightly more than $11.4 \%$ over the same period of the year. In the southeast and southwest of the region, it was obvious that much of the northwest was small (see figure 1d) [4].
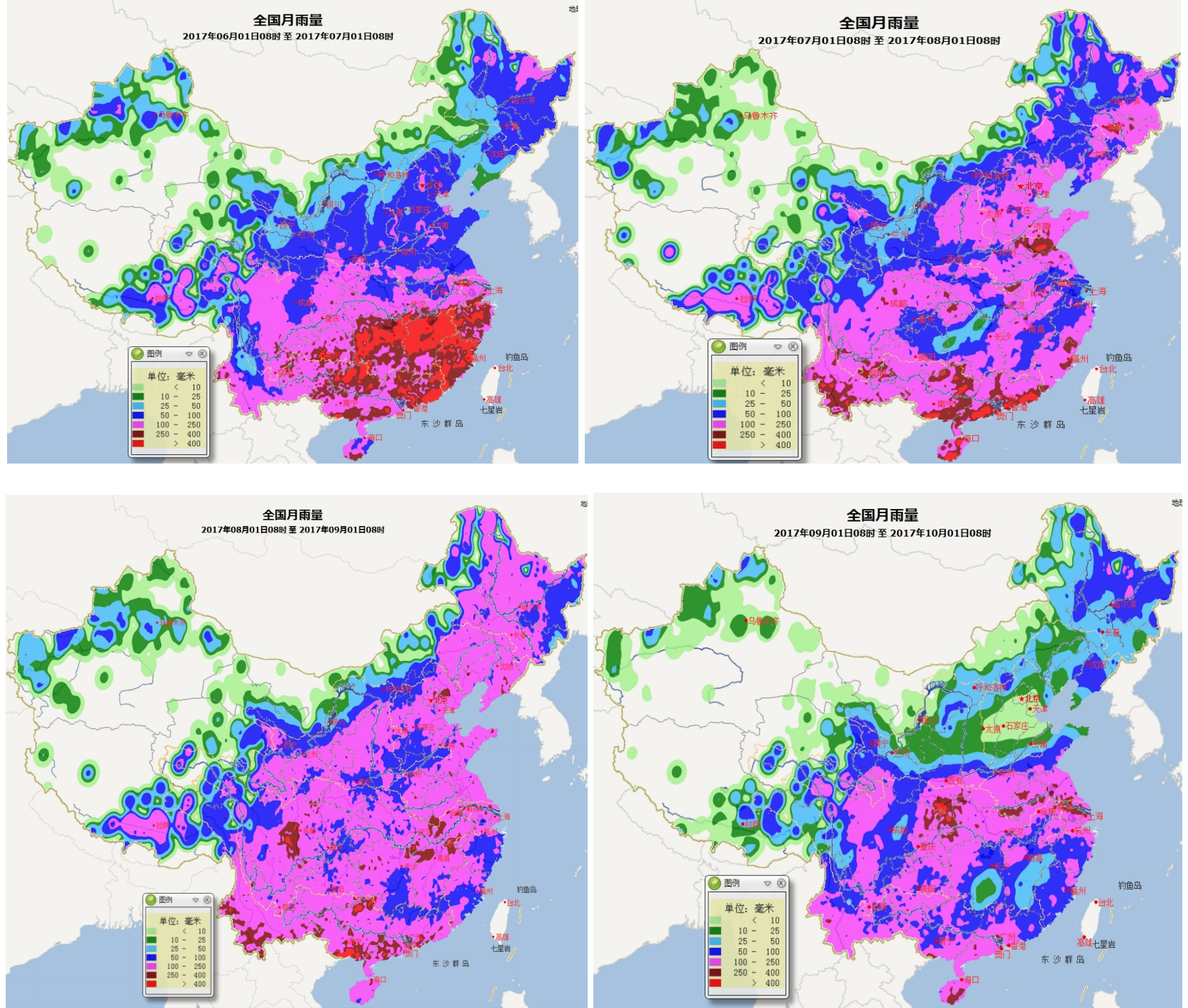

Fig. 1 National rainfall distribution map in the flood season of 2017 ( a. June b. July c.August d.

\section{September )}

\section{Disaster analysis of flood season in western China in 2017}

Floods. Flood disaster is also called flood, which is divided into "flood" and "waterlog". Floods refer to heavy rain, torrential rain, floods, floods, floods, flooding of farmland, destruction of the environment and various facilities. Waterlogging is the accumulation of water caused by too much water or too much concentration or too much backwater [5]. As shown in table 3, the main flood statistics of large rivers flowing through the western region are shown.

Affected by heavy rains and western area water upstream, on July 1, "the Yangtze river flood" 1 formation, middle regional flood occurs, Jiang Duan under the lotus pond in the lancang river and dongting lake and poyang lake across the super $\mathrm{p}$, total $\mathrm{p} 17$ days; In dongting lake, the water system of the xiangjiang river has the highest water level in history, and the flood water and yuanjiang river have exceeded the guaranteed water level. Poyang lake water system has been a major flood in 10 years. Poyang lake has exceeded the warning level. 
Disaster of earthquake and debris flow Barrier Lake. The earthquake disaster is very easy to trigger debris flow and landslide lake and other secondary geological disasters. 21 August 8, 2017 in 19 minutes 46 seconds in aba prefecture in Sichuan jiuzhaigou county $\left(33.2^{\circ} \mathrm{N}, 103.82{ }^{\circ} \mathrm{E}\right)$ magnitude 7 earthquake, the focal depth of $20 \mathrm{~km}$ and a total of Sichuan province and Gansu province in 8 counties affected.

Disaster risk and rescue situation. In the "Yangtze river 1 flood" process, the party members armed police on the first line, the reservoir scheduling war peak. More than 200,000 cadres, militiamen, armed police officers and soldiers, and reserve officers and soldiers were on the frontline of fighting against floods, and promptly organized the transfer of 26,320,000 people who were threatened [6]. The key reservoir groups in the upper middle reaches of the Yangtze river play a significant role in blocking flood, cutting peak and fault peak. The total amount of water is about 12 billion cubic meters, and the peak rate of the reservoir is 30\% 50\%. Facing the continuous heavy rainfall to the middle and lower reaches of the Yangtze river flood control situation day by day serious, areas along the river and tributaries further do a good job in flood control and strengthen the unified scheduling, ready to focus on prevention and control, to strengthen the emergency rescue, maximum limit to reduce disaster losses [7].

Jiuzhaigou in the earthquake disaster rescue, party organizations at all levels and the general party members to stand up, the western theater urgent rescue, armed police, public security policemen, fire fighting forces in the former charge, seismic, geology, mining, safety, health, professional rescue forces quickly inputs such as meteorological, hydrological, widely assemble power overcome difficult.

\section{Conclusions}

In this year's flood season, the weather and climate in the vast areas of the western part of China are not evenly distributed, and the local drought and flood disasters are frequent. The heavy rainfall process is frequent and overlapping, and the local extreme is strong. The high temperature appears early, the intensity is large, the day is many, the influence range is wide. According to statistics, this year's flood season (June - September), the national 1953 station appeared above $35^{\circ} \mathrm{C}$ high temperature weather; 654 station reach standard of extreme events, daily maximum temperature of the western region of Xinjiang turpan $\left(49^{\circ} \mathrm{C}\right)$, toelke Hudson $\left(48.8^{\circ} \mathrm{C}\right.$ ), Shanxi XunYang $\left(44.7^{\circ} \mathrm{C}\right) 166$ breakthrough historical extremum. Since June, the northwest region of middle precipitation more 2 to 5 , Hunan, Jiangxi, Guangxi and other parts of more than 5 into, the more the precipitation of Hunan and Guizhou provinces June for history at the same time the most since 1961; About 30 percent of Inner Mongolia's central and eastern regions and eastern Xinjiang.

From this article to our country in the western region in 2017 flood season water disaster characteristics analysis can be seen, western China floods and landslides, mud-rock flow, lake and other secondary disasters, and weak ability to resist natural disasters, weak infrastructure bottlenecks are still outstanding, the fragile ecological environment, to build "discovery, definition, prevent and combat, transfers, buffer" risk management mechanism, improve the level of risk management.

In order to ensure the safety and safety of flood control and water supply in the western part of our country, it is necessary to improve the situation from the following five aspects.

We need to strengthen monitoring and early warning. We will strengthen the joint consultation with the meteorological and hydrological associations, and timely study and judge the situation of flood control and drought relief. Since the flood, more than 140,000 warning messages have been issued to emergency responders at all levels through an emergency warning information release platform.

We will further consolidate the preparations. Supervise and urge all levels of prevention and related departments to strengthen the responsibility system for flood control and drought relief; Comprehensive investigation of the risk of the Yangtze river collapse; To ensure that the water damage project is completed before the main flood season; We will promptly revise and improve the plans for 
flood control and drought relief; Expedite the completion of rescue teams and material preparation; Strengthen business training and plan drills.

We need to dispatch water conservancy projects. We will strengthen flood control and flood control in the reservoir, rationally determine the operating water level, and make full use of the integrated storage and flood prevention and mitigation benefits.

We should effectively deal with the situation of water situation. We will strengthen emergency preparedness, respond to disasters, and ensure the safety of major targets for flood control and water supply.

We will strengthen the human shadow work. Since the beginning of the flood, a total of 480 aircraft have been carried out in the country, which has effectively carried out 312,000 rain and snow and anti-hail operations.

\section{Acknowledgements}

This work was financially supported by the water resources center website and the central meteorological observatory.

\section{References}

[1] Q.Zhao: Protection of ecological environment in the western region from the perspective of international law, Southwestern University of Finance and Economics press, pp1-263(2010).

[2] Information on https://baike.so.com/doc/13786-14286.html.

[3] Information on http://www.mwr.gov.cn/.

[4] Information on http://www.nmc.cn/publish/observations/precipitation-30day.html.

[5] Information on https://baike.so.com/doc/6025171-6238168.html

[6] S.Z. Wei. 1 of the Yangtze River flood prevention work practice and Enlightenment. Yangtze River (2017).

[7] H.P. Zhang, L. Ling. Sichuan province "8. 8" Jiuzhaigou earthquake relief commendation conference, Sichuan daily (2017). 